\title{
COOPERATION AND COOPERATIVES IN SOUTHERN EUROPEAN WINE PRODUCTION
}

\author{
THE NATURE OF SUCCESSFUL \\ INSTITUTIONAL INNOVATION \\ $1880-1950$
}

James Simpson

Informal cooperation among farmers is a feature of most traditional societies, but the development of cooperatives is relatively new, with few existing in European agriculture before the twentieth century. By the eve of the Second World War the number of agricultural cooperatives varied greatly, both between different countries and crops (Van Zanden 1991, p. 237; Dovring 1956, chap. 5). This paper considers informal cooperation among wine producers and the establishment of formal wine-making cooperatives in three producing countries, namely, Italy, France, and Spain. In the first section I examine three major prob- 
lems facing producers between 1880 and 1950: the appearance of new vine diseases, the persistence of weak wine prices, and rising wage costs. The second section shows the response of producers, and especially how some growers were able to use new biological technologies to obtain significant yield increases. The third argues that rising labor costs and increased technical expertise required in grape and wine production encouraged informal cooperation, not just among small producers, but also between large and small growers. The fourth shows how the growing economies of scale in wine production and marketing, together with the possibilities of improving wine quality, encouraged small producers to establish wine-making cooperatives. The final section considers why, despite the apparent economic advantages of membership for most growers, the diffusion of cooperatives varied significantly between, and within, the three countries. Access to long-term cheap capital, the institutional support of the church and political parties, and the availability of alternative wine-making facilities is shown to be important. By the end of our period, cooperatives were spreading rapidly into new areas, in part because some of these obstacles had been removed, but also because the state considered cooperatives a useful instrument to intervene in the domestic wine market.

\section{LONG-RUN CHANGES IN PROSPERITY}

The lack of homogeneity among wines makes it more difficult than for most other agricultural products to compare prices across geographic regions and over time. For example, a liter of ordinary French table wine in London in 1873 cost just 4 percent of that of a primière cru, a similar price difference to that found in Bordeaux itself. ${ }^{1}$ The evidence of long-run changes in prices shown in Figure 1 therefore has to be taken as only approximate. In addition, the French and Italian figures are national prices, whereas those for Spain come from a specialized wine-producing area in Cataluña, and are less representative of the country as a whole. Cycles of high and low prices are easily visible for all three countries, although the timing often varied. Prices increased everywhere until the mid-1880s, when they began a long decline, bottoming out during the first decade of the twentieth century. The period of high prices witnessed a large growth in the production of artificial wines, often made from cheap "industrial" alcohol, especially sugar beet. The low prices of the first decade of the twentieth century saw the 


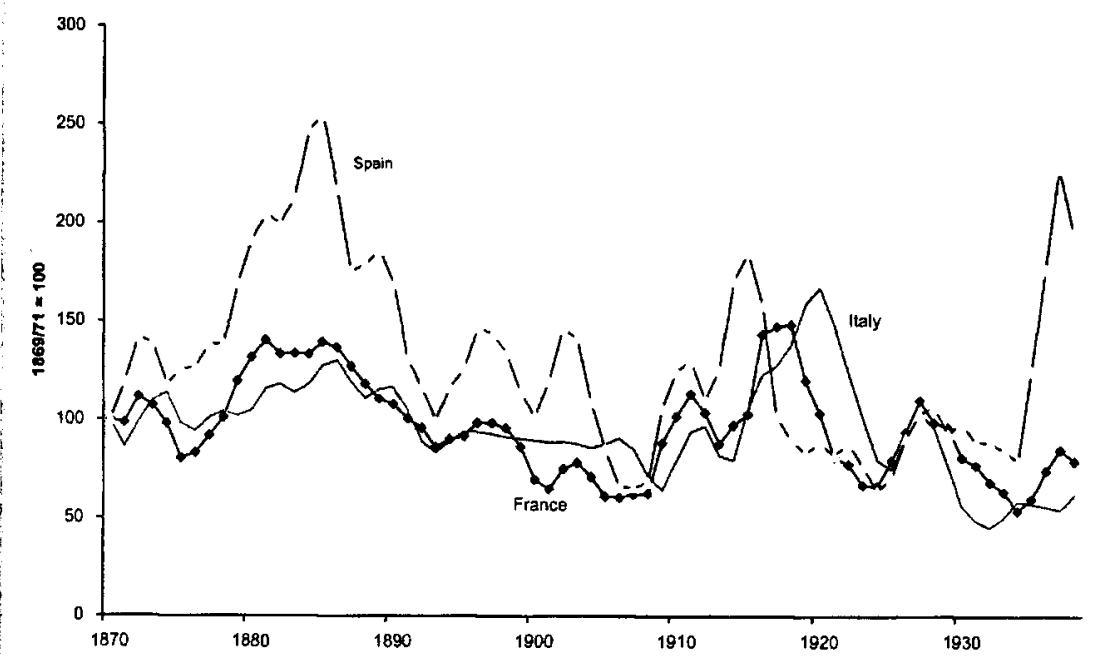

Note: Nominal wine prices have been dividened by the cost if living index of each country. Sources: Italy: "vivo comun", Istituto Centrale di Statistica (hereafter ISTAT) (1958).

France: Ministére du Travail (1933) and Scholliers and Zamagni (1995, pp. 207-208). Spain: Balcells (1980, pp, 377-379) and Maluquer de Motes (1989, pp. 518-519).

Figure 1. Wine Prices in France, Italy, and Spain

first serious attempts to limit the production of these "fraudulent" wines. Between 1901 and 1907 wine producers in the Languedoc in southern France sold their wines at cost price or at a loss during five of the seven years, and the demonstration in Montpellier in June 1907 attracted over half a million protesters (Warner 1960, p. 18; see especially Smith 1978; Frader 1991, chap. 7). During the First World War prices recovered, although growers now faced increasing costs and harvests fell 18 percent in 1915-1919 compared to 1910-1914 in France, and 16 percent in Italy. ${ }^{2}$ As output recovered in the early 1920 s, prices weakened once more. The situation worsened dramatically in the early 1930s, and France introduced legislation to restrict new planting, producers who had very high yields were taxed, and a number of vine varieties which were responsible for the excessively large yields of poor quality wine were banned. During the Second World War the combined shortage of labor and chemicals reappeared once more, and output fell which allowed prices to recover. However, because many of the 1930s restrictions had been relaxed during the war years, the early 1950 s once more saw overproduction, and low wine prices. 
Table 1. Wine Production and Trade

\begin{tabular}{|c|c|c|c|c|c|c|c|c|}
\hline & \multicolumn{2}{|c|}{$1880 / 4$} & \multicolumn{2}{|c|}{$1909 / 13$} & \multicolumn{2}{|c|}{$1925 / 29$} & \multicolumn{2}{|c|}{$1950 / 4$} \\
\hline & Output & Exports & Output & Exports & Output & Exports & Output & Exports \\
\hline France & 33.6 & 2.5 & 58.6 & 2.0 & 56.8 & 1.5 & 58.4 & 2.2 \\
\hline Italy & 30.5 & 2.1 & 50.5 & 1.6 & 45.7 & 1.1 & 47.7 & 1.1 \\
\hline Spain & 21.2 & 6.9 & 14.9 & 3.1 & 23.6 & 4.1 & 17.9 & 1.0 \\
\hline Total & 85.4 & 11.5 & 124.0 & 6.6 & 126.0 & 6.7 & 124.0 & 4.3 \\
\hline $\begin{array}{l}\text { Exports } \\
\text { as \% of } \\
\text { output }\end{array}$ & & $13.4 \%$ & & $5.4 \%$ & & $5.3 \%$ & & $3.5 \%$ \\
\hline
\end{tabular}

While wine producers faced stagnant or falling real prices, important changes in the international wine market were also taking place. In contrast to the Middle Ages and the Early Modern Period, when quality wines and spirits were an important component of European trade, our period saw two important changes. First, the wine trade switched from being one of predominantly high-quality wines to one of table wines and second, from the late 1890 s the traditional major exporters, namely France, Italy, and Spain, saw their markets decline in absolute terms. These changes can be explained by the economic consequences of disease, especially phylloxera, and the growth in urban demand for cheap wines in France. Phylloxera was caused by an aphid that was transported to Europe from the New World, where many vines were immune to it. The speed of infection varied significantly within each country, but in time would destroy almost all of Europe's original vines. The remedy was to replant using American vines as rootstock, and then graft European varieties. As French domestic production slumped from its peak of 83.8 million hectoliters after the exceptional harvest of 1875 (the equivalent of 219 liters per person net of foreign trade), to a low of 23.2 million in 1889 , rising prices elsewhere encouraged growers to increase output. The result was that between 1880 and 1892 France imported the equivalent of a quarter of its own wine consumption, primarily from Spain and, to a lesser extent, Italy. ${ }^{3}$ Even after the recovery of its domestic production, the international wine trade remained dominated by French demand for cheap, strong wines used to blend with domestic ones (see Pan-Montojo and Simpson, forthcoming). But the wine boom for Spain and Italy did not last, as France restricted imports 
Table 2. Changes in Relative Wages and Wine Prices

\begin{tabular}{cccc}
\hline & France & Italy & Spain \\
\hline $1870 \mathrm{~s}$ & 100 & 100 & 100 \\
$1880 \mathrm{~s}$ & 76 & & 82 \\
$1890 \mathrm{~s}$ & 118 & 156 & 124 \\
$1900 \mathrm{~s}$ & 184 & 139 & 134 \\
$1910 \mathrm{~s}$ & 96 & 180 & 130 \\
$1920 \mathrm{~s}$ & 142 & 344 & 288 \\
$1930 \mathrm{~s}$ & 188 & 300 \\
\hline
\end{tabular}

Note: Nominal wages have been divided by wine prices.

Sources: France: wages-Lévy-Leboyer (1971, Table 11, p. 490), cited in Scholliers and Zamagni (1995, pp. 207-209); wine prices-Ministére du Travail (1933, pp. 62-63) and Pech (1975, pp. 511513).

Italy: wages-1870-1879 taken as 1.5 lira; Arcari (1936, pp. 270-201), wine prices-ISTAT (1958, p. 178)

Spain: wages-based on Gutiérrez Bringas (unpublished); wine prices for Sant Pere de Ribes (Barcelona), cited in Balcells (1980, pp. 337-379).

from both countries, and turned instead to its colonies, especially Algeria. Algerian wine production increased from an annual average of 0.6 million hectoliters in 1880-1884 to 7.9 million in 1909-1913, reaching 15.6 million by $1950-1954$. Most of this production was exported, and almost all to France. ${ }^{4}$ As Table 1 suggests, the combined exports from France, Italy, and Spain declined both in relative and absolute terms over the period 1880-1950.

The decline in export opportunities implied that wine producers in southern Europe were increasingly dependent on their domestic markets for sales, where demand was primarily for table wines. Thus in Spain, for example, ordinary table wine accounted for 94 percent of output, fortified wines about four percent, and "quality" wines made up less than two percent (Ministerio de Agricultura 1933, pp. 128-129). However, as French per capita consumption peaked in 1920-1924 at 168 liters/person, in Italy in 1906-1913 at 128 liters/person, and in Spain in 1920-1924 at 96 liters/person (Ministére du Travaill 1934, p. 463), demand was increasingly being driven by population growth.

Another major feature that influenced growers' profitability was the rise in wages, especially from the turn of the twentieth century. Rising wages affected all aspects of agriculture, but viticulture was more labor intensive than most, and the possibilities of introducing labor-saving technologies limited. Whereas in France, agricultural nominal wages increased by perhaps 20 percent over the last quarter 
of the nineteenth century, similar increases were much more localized in Italy and Spain. However, for wine producers everywhere before 1900 any growth in wage costs was more than offset by the buoyant nature of wine prices. This situation changed quickly from the turn of the century, when producers were caught between rising wages and falling wine prices (Table 2). Although in the short term wine prices might rise more quickly than wages, such as during the First World War, in the long run labor costs increased faster. By 1928 a day's wage in France could have bought 54 percent more wine than it had done in 1873,106 percent in Italy, and 162 percent more in Spain. This change clearly benefited consumers, but presented a sever challenge to growers.

\section{THE RESPONSE OF PRODUCERS TO LOW PRICES AND RISING COSTS}

Vines were cultivated under such a wide variety of conditions, that to attempt to describe a "typical" vineyard is impossible. ${ }^{5}$ However, the twin problems of low wine prices and rising wage costs affected directly, or indirectly, all producers. So too did vine diseases, not just phylloxera, but also mildew and black rot, which were particularly virulent with the new American vines. Traditional pre-phylloxera viticulture had consisted essentially of two inputs: land, often marginal for other crops, and labor. Labor requirements involved a number of basic skills, especially pruning, but these could be learned easily enough with informal education in the vineyard. New vines were planted either by layering (provignage), which involved burying a cane from an established vine to the site where the new plant was required, or by planting directly a cutting. Entry costs of traditional viticulture were low.

Phylloxera and other diseases raised these costs in a number of ways. First, by the 1920 s chemicals accounted for around a fifth of annual cultivation costs. ${ }^{6}$ Second, a more scientific approach was required to determine the best rootstock and scion to be grafted for each vineyard, and replanting itself saw an increase in the use of nonfarm inputs. Finally, although the new vines might produce higher yields, they required a better preparation of the land before planting and heavy use of fertilizers.

How did producers of grapes, or manufactures of wine, react to these long-run changes in wine prices, labor costs, and vine disease? We can 
divide their responses into four main areas. First, by switching out of vines into more profitable crops. Second, by using labor-saving technologies in grape production. Third, by increasing yields through recourse to new biological technologies. Finally, by exploiting the growing economies of scale in wine making and its marketing. Two other important areas, namely attempts to improve product quality and government intervention in wine markets to support prices are also noted briefly. We leave to the following section a more detailed discussion of growers' decision making.

Lower wine prices and rising costs, especially after phylloxera, encouraged some farmers to look for alternative crops. Yet in general, winegrowers were loath to uproot vines before their productive life had ended as the high costs of planting had already been paid for, the land was usually of poor quality, and because viticulture provided significantly more employment per hectare than most other crops. In France the area of vines peaked in the pre-phylloxera period at about 2.4 million hectares in the mid-1870s, and the area of the post-phylloxera vines declined slowly from 1.7 million hectares in 1900 , to 1.4 million by the early 1950s. However, as Table 3 suggests, if Algeria is taken as an economic extension of France, then the joint area remains very stable over the first half of the twentieth century. Elsewhere, the total area of vines in Italy remained at around 4.0 million hectares, equivalent to roughly 1.8 million hectares when the area of vines in mixed cultivation is converted into specialized viticulture, and in Spain, the area fluctuated around 1.4 million hectares between 1900 and $1950 .^{7}$ This stability in the area of vines, together with the decline in wine prices, attests to the capacity of producers to adapt, although increasingly in the 1930s and 1950 s, with the need of the state to help distill surplus production.

There were several labor-saving attempts. The use of animal-drawn ploughs in viticulture regions was certainly not new, but was rare and often used with difficulty because of the high density of vines, their irregular planting, and the unscientific nature of pruning prior to phylloxera. The need to replant after the disease allowed growers to reorganize their vineyards with a view to cutting labor inputs. Fewer vines were planted now, but often in straight rows and sometimes the vines were encouraged to grow up wire trellises, which greatly facilitated the use of ploughs and horse-drawn hoes in the cultivation between the rows. The potential labor saved was considerable, and in those areas which could not cut costs because of the steep gradient of the land, such 
Table 3. Area, Output, and Yields in Viticulture

\begin{tabular}{|c|c|c|c|c|}
\hline & $1880 / 4$ & $1909 / 13$ & $1925 / 29$ & $1950 / 54$ \\
\hline \multicolumn{5}{|l|}{ France } \\
\hline Area & 2125 & 1597 & 1520 & 1395 \\
\hline Production & 33.34 & 46.62 & 56.84 & 56.18 \\
\hline Yield per hectare & 15.7 & 29.2 & 37.4 & 40.3 \\
\hline \multicolumn{5}{|l|}{ Algeria } \\
\hline Area & 40 & 137 & 214 & 368 \\
\hline Production & 0.62 & 7.90 & 11.06 & 15.58 \\
\hline Yield per hectare & 15.9 & 57.5 & 51.7 & 42.3 \\
\hline \multicolumn{5}{|l|}{ Italy } \\
\hline Area & 1307 & 1852 & 1808 & \\
\hline Production & 22.48 & 46.02 & 41.19 & \\
\hline Yield per hectare & 17.7 & 25.6 & 23.5 & \\
\hline \multicolumn{5}{|l|}{ Spain } \\
\hline Area & 1710 & 1278 & 1438 & 1483 \\
\hline Production & 21.64 & 14.86 & 23.57 & 17.88 \\
\hline Yield per hectare & 12.7 & 11.6 & 16.4 & 12.1 \\
\hline
\end{tabular}

Note: Area in thousands of hectares; production in millions of hectoliters and yields in hectoliters. Sources: France and Algeria, Lachiver (1988). Italy. MAIC (1892); MAIC (1914); ISTAT (1927). Area of mixed cultivation has been divided by 3.6, and yields multiplied by 1.03 to compensate for grapes not pressed (i.e., table grapes). Spain. Simpson (1985) and Barciela (1989).

as Priorato in Spain, vines were not replanted. The post-phylloxera vines were more susceptible to disease, especially mildew and black rot, and therefore required the use of chemicals. The development of sprays helped keep the rise in costs in check, but so too did row planting, which allowed workers to move more easily among the vines and better control the quantity of chemicals used. Finally, the introduction of new hand instruments simplified both harvesting and pruning operations.

Another possibility was for growers to increase output. Wine yields are a poor indicator of technical progress because they are usually inversely related to quality, vary significantly over the life of the vine, and are difficult to measure when vines are grown among other crops. Despite these limitations, Table 3 shows that yields in France and Algeria were higher than the other two countries and, in the case of France, grew over the period. In France the scientific community became split between those that believed growers should use European vines grafted onto American rootstock and those who preferred using "hybrids" or 
"direct producers." $" 8$ For good wines, there was no debate, as quality was only achieved by grafting. However, the vast majority of growers did not produce quality wines, ${ }^{9}$ and the attraction of hybrids was that they produced large quantities of wine, even though it was often only fit for blending. By 1929 one-seventh of French vines were hybrids, a figure which had grown to almost a fifth or about 300,000 hectares by the early 1940s. Despite government planting restrictions, the figure reached 31 percent of the total area of 1.3 million hectares in 1958, and 42 percent of wine production. ${ }^{10}$ Almost as important as higher yields, hybrids required far less care and chemicals than the grafted vinifera vines (Paul 1996 p. 100). Therefore, as Table 3 suggests, many French and Algerian producers sought to overcome low wine prices and increasing unit costs by maximizing output per hectare.

In Italy hybrids were also introduced slowly in the north and center of the country, but legislation in the 1930s halted their progress, and one report in the late 1940s, while unable to suggest an area of cultivation, claimed that they did not "present a serious threat to our oenology" (B'OIV 1947, no. 195, p. 291). Instead, growers in Italy intercropped on a large scale. In 1913, for example, 76 percent of the north's vines were intercropped, 85 percent of vines in the center, and only in the drier south and islands did it fall to 12 percent (MAIC 1914). By contrast, in Spain the dry climate made the use of hybrids rare (B'OIV 1950 , no. 238 , p. 40 ), yields were significantly lower that in the other countries, and growers in general were unable to intercrop. Instead, whereas in La Mancha growers competed successfully by taking low density-low cost viticulture to an extreme, those in more traditional areas of production, such as Cataluña, were less successful either at reducing production costs (as in La Mancha) or increasing yields (as in the Midi) (Carmona and Simpson 1998; Simpson 1995, pp. 208-214).

Changes in wine making complemented these changes in the vineyards. Traditional wine making was simple and labor intensive. In Italy and Spain, for example, grapes were still crushed by treading in many wine districts at the beginning of the twentieth century (for Spain, see Elias de Molins 1904). A worker during a hard day trod between four and six tons of grapes, producing roughly 25-40 hectoliters of wine (Marcilla Arrazola 1954, pp. 69-70). ${ }^{11}$ Not only was productivity low, but this labor-intensive task coincided with the peak time of employment in the vineyard when labor was scarce. Labor scarcity facilitated the spread of cylindrical crushers in the larger vineyards from the late 
nineteenth century. Productivity improved with Marcilla Arrazola citing a small model, worked by two men, processing 2.2 tons of grapes an hour, or larger, engine-powered models, between five and 10 tons (p. 70). A characteristic feature of the period was that it was in areas of cheaper wines that were at the forefront of technological change. Producers of quality wines were slower to change, in this case because they feared that mechanical crushers would ruin quality (p. 70). ${ }^{12}$

A second advantage of cylindrical crushers was their speed. To make good wine it was necessary to fill vats as quickly as possible, because the entry of newly crushed grapes might set off a secondary fermentation with the must already present. As many small producers owned only one or two vats, which had to serve their whole harvest, new must was inevitably being constantly added during the harvest. In addition, small producers often had to sell the must immediately after its fermentation, as they lacked storage space to mature it. ${ }^{13}$ This encouraged producers to carry out a long fermentation in open vats. A major restriction to improving wine quality was therefore the need for both sufficient and adequate space for fermentation and maturing, and the relatively high investment that adequate storage implied. Although in the interwar period some growers in France began to experiment with a shorter fermentation of five or six days, and to produce a lighter wine which was quick to mature (Loubère 1990, p. 89), this was not an option for many small producers. Indeed, many medium and small producers were unable to produce wine that would keep longer than the spring (Galtier 1958, pp. 338-339). For large-scale producers, as we shall see, new technology allowed wines to be produced more cheaply, of a better quality (greater scale allowed the employment of trained chemists and the provision of a laboratory), and gave the owner greater bargaining power for the sale of wine.

\section{FORMAL AND INFORMAL COOPERATION IN THE VINEYARDS}

The changing technical requirements of viticulture and viniculture led to important changes in the organization of production in a number of regions. Prior to the late nineteenth century most vineyards were small and cultivated using unpaid family labor. Monitoring wage labor was costly because ploughing and hoeing too close to the plant would damage the vine's roots and poor pruning not only affected yields, but could 
also damage the vine permanently (Galassi 1992, pp. 81-82; Hoffman 1984, pp. 315-317; Carmona and Simpson 1999, pp. 292-293). Obviously, where wines fetched high prices, such as in the better vineyards of Bordeaux or Jerez (sherry), estate owners were sufficiently compensated to make the use of wage labor attractive. In most places, however, they were not. Vines were also rarely rented, as tenants would have been tempted to maximize output before the end of their lease, leaving the landowner with a vineyard whose productive life had been significantly shortened. In this section I argue that the weak wine prices, rising wages, and technical change provided incentives for informal cooperation. We shall look at three areas where this occurred. First, the joint purchase of inputs and exchange of technical information among smaller growers. Second, the unequal distribution of land and the heavy labor costs associated with replanting vines encouraged the use of a wide variety of sharecropping contracts. As argued elsewhere, the efficiency of sharecropping depended on adequate incentives for cooperation between landowner and sharecropper (Carmona and Simpson 1999). Finally, some large landowners found they could attract a reliable supply of part-time skilled labor for their vineyards by helping to reduce the costs for smaller family growers of the new scientific requirements associated with grape growing and wine production.

The 1884 law on association in France, which removed the need for government consent for any association of more than 20 people, was designed to help trade union activities for industrial workers, but in fact it had its biggest impact in the countryside, with 5,146 agrarian syndicates and 777,066 members existing in 1910 (International Institute of Agriculture [hereafter IIA] 1911, pp. 256-257). Wine producers were quick to take advantage of the new legislation. In the first instance, disease, especially phylloxera, created major problems which growers could not solve individually. Syndicates collected and circulated information among members on the best way to deal with the disease, and provided information and instructions on the use of new rootstock and grafting. A second area was the purchase of the vines, chemicals, and fertilizers, which benefited growers not just because bulk purchases were cheaper, but because the syndicate was able to check quality, especially important as fraud in all countries was a major problem until the 1920s. Finally, French syndicates helped check another form of fraud, namely that of the production and sale of the "artificial wines," which many growers believed was the prime reason for the weak prices. 
Later syndicates would have an important role in the running of the appellation contrôlées. Elsewhere, syndicates were less important than in France, but the same problems in wine production often encouraged a group response, rather than an individual one.

Informal cooperation was also frequent among producers. In the Languedoc in the early 1950s it was estimated that one man and an animal could be fully employed on seven hectares of vines. Yet at this time about two-thirds of all vineyards, and a quarter of the region's vines were found on holdings of less than three hectares. Some growers had other land, and were thus able to find sufficient work to keep an animal. However, many did not, and the report concludes that it was only mutual aid that allowed vineyards of this size to remain viable (Études et Conjoncture 1956, p. 530). A large number of small owners would also benefit large growers, as we shall see later.

In some areas sharecropping had traditionally been a convenient way for landlords to work their land, as the sharecropper participated in any increase in harvest, and therefore had an incentive to work the vines carefully, thereby reducing monitoring costs for the landowner. Yet problems of moral hazard remained, as sharecroppers might increase the short-term output of the vine at the expense of reducing the vine's commercial life, and then abandon the farm. This problem was overcome in two very different ways. First, in the case of the rabassa morta in Cataluña, the vines were the actual property of the sharecropper. Because sharecroppers would replant the dead or dying vines, the contracts were essentially indefinite until phylloxera struck in the late nineteenth century. The advantage for the landlord of the rabassa morta was that monitoring costs were nonexistent, and management requirements were limited to collecting the agreed share of the harvest, usually a third. Even after phylloxera, many contracts remained longer than the expected life of the vineyard.

A second very different sharecropping model was found in Tuscany and elsewhere in central Italy, the mezzadria. ${ }^{14}$ Here vines were intercropped and wine was only a small part of the sharecropper's output. The central farm (fattoria) took cropping decisions, and management input was significantly higher than found in Cataluña. Contracts were annual, and the sharecropper was required to use all the family labor on his farm (podere). Problems of moral hazard and incentives were overcome by the tradition of renewing contracts annually, although with the landlord retaining the right to evict sharecroppers if they wished. Both 
of these sharecropping contracts had a long history, with the mezzadria being widespread by the thirteenth century, and the rabassa morta from the seventeenth century. Both were also essentially long-term contracts, and appear to have functioned well prior to the late nineteenth century. Then, as has been argued for Cataluña, the impact of rising wages, weak wine prices, and increased costs because of phylloxera reduced incentives for cooperation, as landowners saw management involvement increase sharply, and sharecroppers saw the opportunity cost of their labor rise because of industrialization in neighboring Barcelona (Carmona and Simpson 1999, pp. 303-312). In Tuscany there was also unrest, with strikes over who should pay for the chemicals that the vines now required (De Simone 1979; Radi 1962). Yet the ability of Tuscan landowners to improve product quality and promote the chianti brand name in regions best suited to the vine (the Chianti Classico area was redefined in 1932), or direct resources to other more profitable crops elsewhere suggests greater flexibility than in Cataluña, where vines were intercropped with difficulty, and the most successful diversification away from table wines to cava, a sparkling champagne, still accounted for less than 1 percent of all output in the early 1930s. But high labor costs, weak farm prices, and the growing capital requirements in viticulture now produced tensions in both societies.

Conflict in Cataluña and Tuscany was caused in part because the success of sharecropping in previous periods created expectations for both landowner and sharecropper that were more difficult to realize with the new conditions after phylloxera. However, elsewhere, such as in Campo de Cariñena and Navarra in Spain, the new conditions provided incentives for landowners to offer sharecropping contracts to landless laborers, apparently for the first time (Jaén 1904, p. 104; Sabio 1995, pp. 174-180, 219-220). Replanting after phylloxera required large quantities of labor to clear the old vines and prepare the land for the new ones and, despite the greater capital needs associated with the new vines, viticulture remained labor intensive. Sharecropping was also widely used in the rapid growth of extensive viticulture on large farms which had previously been used for extensive cereals or poor grazing in La Mancha (central Spain) and Puglie (southern Italy). Both areas benefited from low-cost land and labor, and the railways significantly reduced their distance from major urban markets. In La Mancha the very dry climate led to low yields, but also reduced the risks of vine diseases, making chemicals unnecessary in most years. The area of vines 
increased from around 170 thousand hectares in the late 1880 s, to 375 thousand hectares by the early $1930 \mathrm{~s}^{15}$ In Puglie the area of vines increased from 134 thousand hectares in 1879/1883 to 282 thousand in 1913, a figure which was maintained in the early 1950 s. ${ }^{16}$ Like La Mancha, land ownership was concentrated, and contractual conditions for sharecroppers varied, depending on the relative scarcity of labor and the price of wine. ${ }^{17}$ Thus, for example, the appearance of phylloxera and the collapse of wine prices in the late 1880s saw many contracts come to an end, but new ones, often more attractive to the sharecropper, appeared in their place (Inchiesta Parlamentare 1909, p. 445). However, sharecroppers in Puglie were usually only part time, and their main income came from working as wage earners on the large estates (p. 436). Although it is not clear what percentage of vines were worked using sharecroppers, the system in Puglie appears to have also helped keep a skilled, local wage labor force available for larger farmers, a role played by small property owners in the Languedoc.

In the Languedoc large landowners preferred capital-intensive, highyield viticulture, using wage labor rather than sharecropping. Even before phylloxera there had been a move to expand wine production on the fertile plains that increased yields, but at the cost of a decline in quality. This process increased significantly after phylloxera, with the use of such grape varieties as Aramon. But high yields required heavy labor inputs, which was made easier by the fact that the traditional high monitoring costs found in viticulture were slowly being reduced. First, and following the work of Guyot, the new vines of the plains were planted in straight lines and trained to grow up wire trellises. As Guyot (1861, p. 19) wrote, not only did this make it considerably easier to cultivate the vines, but:

A simple glance along the line of vines, permits the owner to spot the skill or the negligence of his vinedressers, just as the foreman can control with the same ease the quantity and quality of work of each of his workers.

Second, pruning knives which, unless kept very sharp often tore the vines, were replaced by the sécateur from the late nineteenth century (Loubère 1978, p. 83; Frader 1991, p. 31). Finally, and as Pech has shown, landownership over the period became increasing concentrated in two different sizes: estates of 40 hectares or more, and those of less than 10 hectares. Large estate owners reduced monitoring costs of wage labor, not just by redesigning their vineyards as Guyot encouraged, but 
Table 4. French Cooperatives and Long-term Borrowing, c. 1910

\begin{tabular}{lcr}
\hline & No. of cooperatives & No. with long-term loans \\
\hline Cheese making, dairies, and butter & 2,485 & 53 \\
Wine & 39 & 31 \\
Starch & 34 & 2 \\
Collective purchase/use of & 23 & 15 \\
$\quad$ agricultural machinery & 20 & 9 \\
Oil mills & 17 & 13 \\
Distilling & 42 & 5 \\
Others & & \\
Notes: Figures for the number of cooperatives and membership are only approximate, as there was often \\
$\quad$ a delay between their formation and the start of production, and those cooperatives which ceased \\
activity often remained active for a number of years in the official figures. \\
Sources: $\quad$ II (1911, pp. 277 and 281).
\end{tabular}

also by increasing incentives for good work. In the first instance, growers with not enough land to employ their whole family fully, found skilled employment on the estates that might be repeated indefinitely on an annual basis if done well. In addition, landowners were sometimes willing to let skilled vinedressers work a six-hour day, finishing at two or three o' clock each afternoon so that they could work their own vines (Smith 1975, p. 365). A second area of incentive for good work was the provision by large producers of technical knowledge, for example, by allowing workers to remove suitable rootstock for their own vineyards, or proving small growers work in their vineyard in exchange for the use of their wine-making facilities (Frader 1991, p. 36). Therefore, the changing nature and growing capital requirements of wine production helped large owners to bargain more effectively for labor, thereby offsetting, at least in part, the rising wages.

\section{THE GROWTH OF COOPERATIVES}

In France, societies for the collective manufacture of cheese-the "fruitières", supposedly date from the twelfth century. ${ }^{18}$ As Table 4 shows, cheese making remained by far the most common of producer cooperatives on the eve of the First World War. This was hardly surprising as they were relatively small, and required limited quantities of capital. The first French wine cooperative appeared in 1901 at Mudaisan, and was quickly followed by another at Maraussan, both in Hérault (Languedoc) (Lachiver 1988, pp. 482-483). The law of December 29, 1901 (together with the decrees of May 30 and August 26, 1907) 
Table 5. Growth in Wine-making Cooperatives in Italy, France, and Spain

\begin{tabular}{|c|c|c|c|c|c|}
\hline & $\begin{array}{l}\text { Number of } \\
\text { cooperatives }\end{array}$ & $\begin{array}{l}\text { Number of } \\
\text { members }\end{array}$ & $\begin{array}{l}\text { Capacity } \\
(000 s \text { hl) }\end{array}$ & $\begin{array}{l}\text { Wine produced } \\
(000 \mathrm{sl})\end{array}$ & $\begin{array}{c}\% \text { of wine } \\
\text { harvest }\end{array}$ \\
\hline \multicolumn{6}{|l|}{ Italy } \\
\hline 1924 (a) & 80 & & & & \\
\hline 1928 (b) & 84 & 10,732 & 1,200 & 1,000 & \\
\hline 1931 (c) & $98^{*}$ & 12,481 & 917 & 857 & \\
\hline 1932 (c) & 128 & 15,909 & 1,220 & 958 & \\
\hline $1938(d)$ & 147 & 18,820 & 1,566 & 934 & \\
\hline 1951 (e) & 161 & & & & \\
\hline \multicolumn{6}{|c|}{ * plus 17 more in construction. } \\
\hline \multicolumn{6}{|l|}{ France } \\
\hline $1908(f)$ & 13 & & 120 & & \\
\hline $1914(\mathrm{~g})$ & 79 & & & & \\
\hline $1920(f)$ & 92 & & 1,000 & & \\
\hline $1929(f)$ & $630+$ & & & & \\
\hline $1939(f)$ & 827 & & 12,000 & & \\
\hline $1943(f)$ & 852 & 142,000 & 14,480 & & \\
\hline $1952(e)$ & 1,023 & 214,306 & 20,904 & 13,461 & $25.4 \%$ \\
\hline \multicolumn{6}{|c|}{+464 were wine cooperatives, and 252 distilleries. } \\
\hline \multicolumn{6}{|l|}{ Spain } \\
\hline Early 1920s (h) & $50-60$ & & & & \\
\hline 1951 (e) & 215 & 60,000 & & 1,500 & \\
\hline $1953(\mathrm{e})$ & 263 & & & 2,422 & $12.8 \%$ \\
\hline
\end{tabular}

Sources: (a) Marchesi, 1925, pp. 81-84.
(b) IIA, 1931, p. 39
(c) ISTAT, various years.
(d) ISTAT, 1940
(e) B'OIV 1955, no. 290.
(f) B'OIV 1952, no. 254.
(g) Lachiver, 1988, p. 482.
(h) Rivas Moreno, n.d., p. 280.

allowed agrarian cooperatives of production and sale access to longterm credit at the almost uniform rate of 2 percent interest over 25 years. Capital was provided by the state, but lent through regional credit banks, who were responsible for the loans. Local banks did the monitoring therefore, but transaction costs were greatly reduced because cooperatives were required to establish a specific legal structure if they wished to receive loans.

Access to long-term credit was certainly not the only, or even the principle reason, for the founding of these early cooperatives. Many were strongly influenced by socialist ideology, and were seen as a solu- 
tion to the extremely low wine prices between 1900 and 1907 . It was under these conditions that "les vignerons libres de Maraussan" established a producer's cooperative to sell wine to consumer cooperatives in Paris. But as early as 1906 the members had constructed and equipped a modern cooperative winery, which had an initial capacity of 15,000 hectoliters, at a cost of 175 thousand francs. The Ministry of Agriculture contributed 30 thousand francs, the local regional bank (under the 1906 law) provided a long-term loan of 109 thousand francs, and a further 30 thousand francs was raised from consumer cooperatives in Paris. The subscription of the 120 members was just 25 francs each (Gide 1926, pp. 129-131). The example of Maraussan provides two important insights, namely the contribution that ideology, in this case socialism, can play in setting up a simple wine cooperative, and the very high capital costs involved in constructing a large, modern winery.

Although the low wine prices between 1900 and 1907 encouraged the formation of cooperatives - the "filles de la misère," Table 5 shows that numbers continued to grow steadily throughout the first half of the twentieth century, with only a temporary halt during the two world wars. By the time of the economic crisis of the early 1930s, cooperatives numbered 630, significantly more than in either Italy or Spain. The severe difficulties of the early 1930s saw a number of attempts at state intervention in the wine market (Warner 1960, chaps. 6, 7, 8), and cooperatives were seen as a useful instrument for policy implementation. By the early 1950s cooperatives produced about a quarter of all French wines, a figure that reached over half in the south. ${ }^{19}$

The French experience was not matched by either Italy or Spain. In both countries the first wine cooperatives predated those of France. In Italy a cantina sociale was established at Bagno a Ripoli, near Florence in 1888 , and by 1910 there were reported "slightly in excess of $150 ., 20$ But most cooperatives were short lived, and in 1924 numbers were down to 80 , before recovering to 128 in 1933 , and just 1.3 percent of wine production (ISTAT 1933, pp. 145 and 147). We shall comment later on why this initial growth of Italian cooperatives faded so quickly. In Spain it was claimed that there were 215 wine cooperatives and 19 distilleries in 1952, with a total membership of 60 thousand growers, and producing about 1.5 million hectoliters, or 10 percent of national output (B'OIV 1952, no. 253, p. 63). In Spain, as in France and Italy, the number of wine cooperatives was increasing very fast in the early 1950s, but these figures probably include a number whose winemaking 
facilities were still under construction. Furthermore, even if the production figures are correct, the early 1950s harvests were exceptionally low. Prior to the 1936-1939 civil war, wine cooperatives in Spain were probably well below a hundred.

Wine cooperatives, were established for three distinct activities: the crushing, fermenting, and pressing of grapes; the maturing and selling of wines; and the processing of the wine lees-the remains of the grapes after they had been crushed to make both spirits and tartic acid. These activities suggest five economic reasons why small growers were attracted to setting up a cooperative.

In the first instance, there were economies of scale in wine making, as we have already noted. These economies became increasingly apparent as the period progressed. By the early 1950 s the average size of a wine cooperative was 15,000 hectoliters, costing 60 million francs, a figure well beyond the means of medium-sized producers (B'OIV 1954, no. 283 , p. 49; Galtier 1958, pp. 338-339). The greatest economies were achieved not in the production of quality wines, but with table wines, where large quantities could be pressed and matured together. There were, however, limits to the economies of scale, even with table wines. For example, one of the major problems during fermentation was the need to control temperature. If vats were too large, then the wine became too warm and the fermentation process stops. In general, 300 hectoliters were considered about the maximum, although concrete vats, which absorbed more heat than wood, might be slightly larger. In one very large private winery in Aude (Languedoc) with a capacity of 1,400 hectoliters a day, fed from 215 hectares of vines and producing 30,000 hectoliters of wine, 20 fermenting vats, each with a capacity of around 350 hectoliters were used. ${ }^{21}$ In fact, the first half of the twentieth century probably saw a reduction in the size of vats, as the fermentation process became better understood (B'OIV 1952, no. 254, p. 43). Likewise, there were also limits to the size of the maturing vats. Therefore, according to one report, unit capital costs of a simple winery of 15 thousand hectoliters were the same as one with a 175 thousand capacity (p. 41). ${ }^{22}$ By contrast, unit operating costs of larger wineries were often lower, and one cooperative in 1950 which processed 152 thousand hectoliters, used only 40 percent of labor per hectoliter than a much smaller one of 11 thousand hectoliters. Another study shows the cost of wine making in 12 cooperatives in 1949 varied between 78 and 169 francs per hectoliter (both cited in Galtier 1958, p. 377). In part, cost compar- 
ison is made difficult because of the treatment by cooperatives of interest and depreciation in their accounting. However, and in conclusion, although economies of scale no doubt were a factor in the decision in establishing a cooperative, the fact that wine making represented only between 3 and 8 percent of the final price suggests it was probably not crucial (p. 377).

Perhaps more important than cost savings was the improved quality and consistency of wines produced by better management and technical skills. The scientific knowledge concerning the nature of wine and the problems associated with its making and storing increased significantly after the publication of Pasteur's major work in 1864. Although technical debates on such issues as the ideal fermentation time, or the best way to treat a wine that had become unstable would continue, the technical equipment and skills required in viniculture if drinkable wine was to be consistently produced had by the early twentieth century, if not before, moved well beyond what the majority of grape producers could either understand, or carry out. As Galtier notes, cooperatives created a new type of professional-a manager who was both an oenologist and who could also attend to the legal and commercial sides of the business. At first, a respected member of the community often directed the technical processes, but increasingly the larger cooperatives looked for trained agronomists, and especially oenologists. In France, from 1939, the Ecole Nationale d'Agriculture in Montepellier started annual courses specifically for cooperative technicians (p. 376). Quality wines could, and indeed were, produced in cooperatives. The fact that fermenting vats were about 300 hectoliters allowed medium-sized producers the possibility to use the superior technology (and scientific knowledge) available in the cooperative, but keep their wines separate from the rest. After fermentation, the wines were collected from the cooperative and matured in their own private cellars.

Economies of scale in marketing were a third advantage. Cooperative members had better access to urban markets by producing large quantities of a standardized wine under scientific conditions, than by trying to sell their own production individually. Pech notes how one giant private producer with facilities to produce 100 thousand hectoliters, the Compagnie des Salins du Midi (C.S.M.) received on average 19.25 francs per hectoliter in the period 1893-1913, against a regional average of 16.00 francs. By contrast Gélly, a small producer in the same region who produced little more than 400 hectoliters, received 27 per- 
cent less than the C.S.M. during the period 1893-1906. Of greater importance, in years of low prices the difference was even greater, with Gélly being paid only 4.8 francs in 1904 against 11.5 francs, received by the C.S.M. (Pech 1975, p. 158). As noted above, the Maraussan cooperative was initially established for the sale of wines, rather than their production. Finally, although higher prices were achieved in part because cooperatives postponed the sale of the wine (and thereby avoided the low prices common immediately after the harvest), members were usually able to obtain loans from the cooperative as soon as they handed over their grapes.

A fourth advantage was that cooperatives reduced a farmer's labor requirements by increasing capital, a feature not usually considered necessarily beneficial on small, family farms. However, because labor was saved at the harvest time when family resources were fully stretched, it often reduced the growers' need for wage labor, rather than making family labor idle. Furthermore, the fact that growers no longer fermented all their grapes in a single vat, which required the harvest to be collected as rapidly as possible, further reduced the need to employ wage labor (Galtier 1958, p. 340).

Finally, cooperatives were established for processing the remains of grapes after wine making. Small producers had often traditionally produced spirits themselves, but new technology allowed cream of tartar to be produced.

\section{WHAT EXPLAINS THE SUCCESS OR FAILURE OF WINE COOPERATIVES?}

In the previous section we saw that the growth of cooperatives varied between countries. Of particular interest is the Italian case where, after an early rapid growth, numbers then declined. For the historian, even more difficult than establishing with certainty the number of cooperatives and their membership in any single year, the question is whether numbers changed because new cooperatives came into operation, or because old ones disappeared. For Italy it is possible to illustrate the short life of many of the early cooperatives in a little more detail. In 1904 the government established a fund of 700,000 lire to encourage the modernization of wine-making facilities, and the report published in 1908 gave details of 33 cooperatives which successfully took part. Of these 33 cooperatives, only 12 were still active 25 years later in $1929 .^{23}$ 
By 1958 of these surviving 12 , three were still definitely operational (Oleggio and Mombaruzzo in Piemonte, and the Cantina Sociale della Pioppa at Carpi in Emilia), and another five perhaps working. ${ }^{24}$ Of the remaining four, three were not mentioned in the 1958 survey and the fourth, Soave (in Verona) is shown as having started in 1930, with the original one presumably having ceased to operate. Therefore, our sample of 33 in 1908 was severely depleted by the late 1920 s, which supports contemporary opinion that Italian cooperatives found it difficult to remain active for very long (Gide 1927, p. 92).

What explains the differences in the success of cooperatives, both between different countries and within them? In the first instance, access to capital was critical. Most writers argue that the long-term, low-interest loans provided by the French government were a major incentive for growers to set up their cooperative. As we have noted, the state provided directly or indirectly four-fifths of the capital requirements for the Maraussan cooperative in 1906, a figure which was similar at the end of our period. ${ }^{25}$ In addition, the state provided free technical information on the construction and equipping of the cooperative and favorable tax conditions. These advantages which French wine producers enjoyed can best be appreciated by looking at the situation in Italy and Spain. In Italy the lack of government-backed loans implied that capital was difficult for cooperatives to obtain and expensive, and was frequently cited for their slow growth in the 1920s (for example, Gide 1926, pp. 94-95). In Valencia in Spain the small growers in Utiel had to wait 22 years before they were able to construct their own winery, while in neighboring Requena, cooperative members themselves constructed the building over a three-year period (Piqueras 1981 , p. 270). One recent study of the pre-civil war period in Spain concludes that, although the financial obstacles to establishing cooperatives were not the only ones, they were decisive (Pan-Montojo 1994, p. 361). But in both countries the situation by the early 1950s had improved significantly. In Italy the law of 1931 provided three million lire of state money for non-repayable grants of up to 20 percent of longterm investment for new cooperatives, and 15 percent for improvements in those already in operation, and loans also became easier to apply for. The 1952 law provided conditions not so different from those in France, with state-backed loans of up to 75 percent of capital expenditure, at 3 percent interest (B'OIV 1955, no. 290, p. 49). In Spain, by the early 1950s, the Ministry of Agriculture was also providing loans of 
up to 80 percent of the capital cost of cooperative installation, over a 10-year period and at 2.5 percent interest (B'OIV 1952, no. 254, p. 32).

A second factor in explaining the different rates of growth of cooperatives is ideology. Small growers often faced high transaction costs, both in organizing among themselves and in the practicalities of establishing the cooperative winery. These could be reduced by the presence of outside agents. In France the early success of many of the small cooperatives in the south, and in particular in Var, is attributed to the role played by socialism. Furthermore, as the Catholic Church was also very active in some areas, competition between the two helped bring material benefits to cooperative members (Cleary 1989, p. 46). By contrast, in Italy one of the chief weaknesses of the cooperative movement as a whole was "the rapid and excessive multiplication of societies having the same aims and, inevitably, competing with each other" (Lloyd 1925 , p. 2). By the early 1920 s there were three main groups-the Lega Nazionale delle Cooperative (socialist), the Confederazione Cooperativa Italiana (Catholic), and the Sindicato Italiano delle Cooperative (fascist) (Cotta 1935, pp. 4-5). With the coming to power of the fascists in 1922, cooperatives were reorganized into a single body, L'Ente Nazionale Fascista dell Cooperazione. The closure of many socialist cooperatives explains, at least in part, the stagnation of the movement in this period. By contrast, in Spain, it was the Catholic Church that provided the ideological stimulus and institutional framework for the cooperative movement, accounting for about 90 percent of the total in 1919 (Garrido 1996, p. 61). But although membership reached over half a million by the early 1930s, few cooperatives had facilities to process farm products (Garrido 1996; Pan-Montojo 1994, pp. 361-365; Simpson 1995, pp. 228-231). By contrast, the socialist party's interest in agriculture was limited to the landless jornaleros.

The significant variations in the regional concentration of cooperatives suggest that there were factors other than just access to long-term capital, or the organizational capacity of outside agencies. By the early 1950s, 71 percent of all French cooperatives were found in the south, attracting over half of all growers. In Italy 83 percent of cooperatives were in the north, and in Spain, 79 percent were found in the Mediterranean and Navarra. It is perhaps not surprising to find cooperatives in regions where viticulture was of importance. However, and what has to be explained, is why cooperatives were rare in some major wine-producing areas. One argument is the supposed opposition from commer- 
cial wineries. Growers, it is argued, were underpaid for their grapes because commercial wineries had excessive market power, and faced opposition when they tried to establish their own cooperative. Although it is unlikely that established private wineries would welcome competition, it is difficult to prove that they systematically were able to distort local markets, or successfully stop the establishment of cooperatives. Indeed the limited evidence suggests that their influence was probably small.

It is true that before motor transport reduced the problems of distance, and except in villages with a heavy concentration of vines, most growers would have had a limited number of commercial outlets for their grapes. ${ }^{26}$ However, and in contrast with the Danish cooperative dairies of the late nineteenth century, there appears to have been limits to private wineries market power. The creation of a specific asset (the winery) implied that the owner was as dependent on an adequate supply of grapes, as the grower was to find a market. Furthermore, because growers could be paid by both the quantity and sugar content of their grapes, the problems of asymmetric information which gave cooperatives an important competitive advantage in the manufacture of Danish butter were considerably less in wine making. ${ }^{27}$ But, as we have seen, large wineries were often able to obtain higher prices than small producers, especially in periods of overproduction. It was in periods of overproduction and low prices, rather than market abuse on the part of private wineries, which was behind the large wave of cooperatives that were founded in the early 1900s and early 1930s.

The geographic distribution of cooperatives prior to the Second World War reflects to a certain extent farm size and land ownership patterns, which might suggest political opposition to them was greater in certain areas. A successful cooperative was likely to be found in a village with both a sufficient volume of grapes, and fragmentation of land ownership. In France in 1951 the average cooperative had a capacity of 20 thousand hectoliters, and a membership of 209, producing about 100 hectoliters each (Table 6). Yet within the country there were important differences. In particular, cooperative members in the Languedoc were smaller growers (56\% growers, producing only $26 \%$ of the wine), whereas in the "rest of France," they were well above average size ( $3 \%$ of the total, producing $23 \%$ of the wine). In the "rest of France" cooperatives had fewer members (164 members against 212 in the Languedoc), but each produced over twice as much wine (119 hectoliters 
Table 6. Regional Distribution of Wine Cooperatives, Early 1950s

\begin{tabular}{|c|c|c|c|}
\hline & No. of cooperatives & $\begin{array}{c}\% \text { of growers } \\
\text { in } \\
\text { cooperatives }\end{array}$ & $\begin{array}{c}\% \text { of wine produced } \\
\text { in cooperatives }\end{array}$ \\
\hline \multicolumn{4}{|l|}{ A. FRANCE, 1951} \\
\hline Languedoc-Roussillion & 521 & 56.1 & 26.4 \\
\hline Lower Rhone & 181 & 53.1 & 56.0 \\
\hline Gironde & 61 & 14.2 & 21.0 \\
\hline Rest of France & 223 & 3.0 & 22.8 \\
\hline TOTAL & 986 & 13.0 & 28.0 \\
\hline
\end{tabular}

B. ITALY, 1952-1953

\begin{tabular}{lccc}
\hline & No. of cooperatives & \% of total & $\begin{array}{c}\text { \% of nation's wine } \\
\text { produced in region }\end{array}$ \\
\hline North & 172 & 82.7 & 40.3 \\
Center & 10 & 4.8 & 23.0 \\
South & 17 & 8.2 & 25.1 \\
Islands & 9 & 4.3 & 11.6 \\
TOTAL & 208 & 100.0 & 100.0 \\
\hline
\end{tabular}

C. SPAIN, 1952

\begin{tabular}{lrrr} 
Andalucía & 5 & 2.3 & 12.5 \\
Northern Spain & 1 & 0.4 & 9.4 \\
Castilla, León \& Extremadura & 6 & 2.8 & 17.1 \\
Castilla-La Mancha & 26 & 12.1 & 21.7 \\
Upper Ebro & 50 & 23.3 & 6.3 \\
Aragón & 4 & 1.9 & 3.2 \\
Mediterranean & 122 & 56.7 & 29.6 \\
Canary Islands & 1 & 0.4 & 0.2 \\
TOTAL & 215 & 99.9 & 100.0 \\
\hline Sources: France: B'OIV, 1954, no. 283, pp. 46-47. & & \\
\multicolumn{2}{l}{ Italy: B'OIV, 1955, no. 290, p. 47 and ISTAT, various years. } \\
\multicolumn{2}{l}{ Spain: B'OIV, 1955, no. 290. }
\end{tabular}

against 53). Information of individual production within a cooperative is unfortunately scarce. In Vergèze (Languedoc) average production was 112 hectoliters, but over half the members contributed less than 50 hectoliters each, compared to 12 percent who were responsible for half of total output, at an average of 485 hectoliters per member. This suggests that although cooperatives might attract large numbers of small part-time growers, half the production was provided by full-time professional grape growers.

Cooperatives were rare in both Puglie and La Mancha. The relatively low yields of these regions implied that a cooperative of 15,000 hectoliters required a feed area of approximately 1,000 hectares in La Man- 
cha or 715 in Puglie in the early 1920s. ${ }^{28}$ Sharecropping, as we have seen, was an important feature in the rapid growth of viticulture in both these regions, but sharecroppers had little capital, and it was left to landowners and wine merchants to construct the wine-making facilities. Likewise in the traditional sharecropping region of Tuscany, it was the central farm-the fattoria-which made the wine. For sharecroppers, the temporary nature of their contracts was another obstacle for the long-term investment in a cooperative. The cantina sociale in Piumazzo (Modena) tried to overcome this problem by having two types of members: permanent ones (soci effectivi), who could only leave the cooperative if they sold their land (or in other, strictly defined circumstances), and annual members (soci annuali) - sharecroppers who could use the cooperative facilities, but who played a very limited role in the administration (Clique 1931, pp. 246-247). But in general, cooperatives were late to appear in those regions where sharecropping was found. In 1950 there were still no wine cooperatives in Tuscany, despite the region producing about a tenth of the nation's wine. Cataluña was a notable exception, although in this region, contracts were for several decades giving sharecroppers' greater stability to make the long-term commitment that cooperative membership required.

Another explanation was wine quality. Most producers used a number of vine varieties, and the final product of each grower was different, depending on the mix of grapes. Although one of the attractions of cooperatives was their ability to produce a standardized product, they in general found it hard to price grapes other than by their sugar content. One possibility, common in Italy during the 1920 s or with some of the middle-quality Bordeaux wines in the 1930s and 1940s, was for growers to bring only part of their harvest to the cooperative, and press at home or sell to private wine producers, those grapes which they felt produced the best wine (Clique 1931; Roudie 1994, p. 282). However, if this helped overcome the problem of the diversity of grape varieties in a region, it had two obvious negative consequences. First, growers who only used the cooperative for perhaps half their production would have less interest in its long-term success. Second, it was the poor-quality wines made from the least desirable grapes, which was considered one of the major weaknesses of the Italian cooperatives in this period (Berget 1925, cited in Clique 1931, p. 241). Growers looked to cooperatives as an outlet for their poor-quality grapes, a fact encouraged by governments which enforced compulsory distilling of surpluses in the 
early 1950s. Grape variety also helps to explain the high density of cooperatives in the Languedoc, where they had become more standardized than in most other regions, with the aramon (red wines) and clairette (white) predominating (Gide 1927, pp. 92-93).

A final factor was clustering. Cooperatives, at least prior to the Second World War, were in general found around a major center of commercial viticulture in each country, namely the Languedoc, Piedmonte, and Cataluña. After the first few cooperatives were established, each region used its major wine journals, wine research centers, specialist equipment producers, and so on to help in the diffusion of the cooperative concept. ${ }^{29}$ To reinforce this, regional federations were founded whose aim, among others, was quite naturally to establish more cooperatives. Even when national associations appeared, meetings and conferences tended to be held in those areas where the concentration of cooperatives was already high. This did not make it impossible for cooperatives to develop in new areas. However, when the Compagnie ferroviaire d'Orleans wanted to encourage producers in southwestern France to build cooperatives, it had to organize visits for prospective members to the Burgundy, to see one in operation (Roudie 1994, p. 276).

\section{CONCLUSION}

This paper has shown how, in the face of adverse wine prices and rising production costs, grape and wine producers looked not just to new technologies, but also to formal and informal cooperation as a means of remaining competitive. Although it is the large wineries that are the most visible source of cooperation among growers, this paper has tried to place equal emphasis on other informal cooperation. Contracts often proved remarkably adapt at changing to different circumstances, and informal and unwritten contracts of a wide nature existed, both helping landowners secure adequate skilled labor at cheaper rates, and for smaller, sometimes illiterate growers, to capture some of the benefits of the scientific revolution through which viticulture was passing.

Cooperative wineries provided access for small and medium-sized producers to the rapidly improving scientific knowledge of wine making, together with equipment that was far beyond their means to obtain privately. Cooperatives also improved growers' bargaining power for selling the wine. However, without access to long-term 
credit, it was difficult for cooperatives to be established. By the end of our period the movement was entering a new phase in France, with wine cooperatives being used by the state to help coordinate intervention in the wine market, both by limiting the types of vines used by growers, and by controlling the release of wine onto the national market. The extent by which these forms of cooperation among producers were efficient is more difficult to measure. Without the formal and informal cooperation shown in this paper, there can be little doubt that the speed of the rural exodus would have been faster both before and after 1950. But wine cooperatives appear to have competed among themselves and prices, if not wine quality, moved in a favorable direction for consumers in all three countries.

\section{ACKNOWLEDGMENTS}

This research was made possible by a grant from the Spanish government (PB97-0085). I would like to thank the librarians at the FAO library for help in locating materiel, and to Juan Carmona for allowing me to draw on our joint research. Juan Carmona, Pedro Fraile, Samuel Garrido, Juan Pan-Montojo, and Joan Roses made helpful comments, as did participants to the seminar at the Universidad Carlos III de Madrid and the I Symposion de la Asociación Internacional de Historia y Civilización de la Vid y el Vino in El Puerto de Santa Maria, April 1999.

\section{NOTES}

1. The Wine Trade Review, cited in Pan-Montojo and Simpson (forthcoming) and Roudié (1994, p. 36), who notes that a leading Medoc sold for around 22 times that of a Saint-Macaire, Blaye, or Bourg in 1840.

2. In Spain, which was recovering from phylloxera, output increased by a third. The 1915 harvest everywhere was especially small on account of climatic conditions and the lack of chemicals for growers to protect their vines against mildew.

3. Production averaged 29.5 million hectoliters, exports 2.4 million, imports 9.7 million, and consumption 36.8 million (Ministére du Travail 1934, pp. 179-180). By contrast, between 1868 and 1878 average domestic production was 55.5 million hectoliters.

4. For example, in 1925-1929 average production was 11.1 million hectoliters, of which 8.1 million were exported, and 97.6 percent of this figure went to France (Ferrara 1931, pp. 114-115).

5. Marescalchi (1924, pp. 5-12), for example, found significant differences in production costs in Italy in the early twentieth century. 
6. The exact amount naturally varies significantly between vineyards. A figure of 18 percent was given for Tarragona (Spain) in 1921 (Instituto de Reformas Sociales 1923, pp. 161-174).

7. The area of mixed cultivation is converted to specialized crops by dividing it by 3.6, a coefficient given in the Bulletin de l'office international du vin (hereafter B'OIV) (1951, no. 240, p. 7) and used throughout this paper.

8. "Hybrids" were vines planted directly, which needed no grafting.

9. By the early 1950s about 10 percent of all French wines belonged to an appellation contrôlée (AOC), with smaller percentages in Italy and Spain (Lachiver 1988, p. 584).

10. Paul (1996, pp. 102 and 105), where the debate over the introduction of hybrids is fully covered.

11. This is equivalent to the output of about one hectare.

12. For example, in Spain by the early 1950 s, crushing by treading had disappeared in "almost" all wineries, with the notable exception of sherry making in Jerez de la Frontera.

13. This was true of much of Barcelona in the $1880 \mathrm{~s}$, for example. Archivo del Ministerio de Agricultura, 81-3.

14. The literature on the workings of mezzadria is considerable (see for example, Biagioli 1987; Galassi 1992: Pazzagli 1973).

15. For viticulture in La Mancha, Simpson (1995, pp. 206-214) and for sharecropping, Carmona (unpublished).

16. MAIC (1892, p. xxxiv; MAIC 1914, p. 16), which notes that there was no intercropping (ISTAT 1954).

17. Inchiesta Parlamentare (1909, Puglie, pp. 442-445). An excellent brief survey of this source, and the use of multiple contracts in southern Italy is to be found in Galassi and Cohen (1994).

18. IIA (1911, p. 280). In northern Italy a similar institution, the turnario sociale dates from slightly later.

19. In Algeria, by contrast, it was 17 percent.

20. IIA (1915, p. 152). A further 40 cooperative distilleries were also active. The cooperative at Bagno a Ripoli was shortlived.

21. The producer was Jouarres, at Minervois (Barbut, cited in Loubère 1978, p. 199).

22. In Spain, by contrast, a winery with a 20,000 hectoliter capacity was estimate to cost two million pesetas, with smaller ones increasing by 15 percent, and larger ones falling by the same amount (B'OIV 1952, no. 254, pp. 31-32.

23. I include Mombaruzzo (Piemonte) among these 12, even though in 1929 and 1931 it was not active, because it appears in a 1958 list. Sources used are MAIC (1908); Friedmann, cited in Clique (1931, pp. 243-245); Po (1931, pp. 37-47); and Cosmo (1958, pp. 95-131).

24. For these five, although cooperatives existed in the same villages in both 1908 and 1958, the 1958 list fails to provide a date for when the cooperative started.

25. The state provided 20 percent directly and a loan of 60 percent was available from the Caisse Nationale de Crédit Agricole, with members required to find the remaining 20 percent, divided according to individual harvest size (Galtier 1958, p. 346). 
26. Gide noted in the mid-1920s that a grower with motor transport would be sufficiently wealthy not to have to belong to a cooperative (1926, p. 138), but by the early 1930s lorries were used to transport grapes from collection points to the cooperative, at a distance of 10 or 15 kilometers (Clique 1931, p. 97).

27. Danish dairy cooperatives were successful because they established trust with farmers, which was different for private cooperatives to emulate (it was difficult to measure the butterfat content of milk prior to the late 1890s), and because joint ownership could impose discipline on members more easily (see Henriksen 1999, especially pp. 66-72).

28. Average yields in 1922/1926 were 15 hectoliters in Ciudad Real, and 21 in Puglie.

29. One major exception to this rule was Navarra, the home to 22 percent of Spain's wine cooperatives in the early 1950s. The explanation here is a different form of clustering, in this case the province had an unusually high level of cooperative activity in all areas of agriculture (see, especially, Majuelo and Pascual 1991).

\section{REFERENCES}

Antúnez, Luis (1887). Informe sobre la crisis actual de las industrias pecuaria y vitivinícola. Barcelona: Tip de Salvador Moreno.

Arcari, Paola (1936). "Le variazioni dei salari agricoli in Italia dalla fondazione del Regno al 1933." Annali di Statistica 36.

Balcells, Albert (1980). El problema agrario en Cataluña. La cuestión Rabassaire. Madrid: Ministerio de Agricultura.

Barciela, Carlos (1989). "Sector agrario." In Albert Carreras (Ed.) Estadísticas históricas de España siglos XIX-XX. Barcelona: Fundación Banco Exterior.

Biagioli, Giuliana (1987). "The Spread of Mezzadria in Central Italy: A Model of Demographic and Economic Development." In Fauvre-Chamoux (Ed.) Evolution agraire et croissance démographique. Liège: Ordina Editions.

Carmona, Juan (unpublished). "Las formas de explotación de la viticultura manchega, 1870-1960."

Carmona, Juan, and Simpson, James (1998). "Vines and Sharecropping: The Case of Cataluña: 1700s-1930s." In Francesco Galassi, Kyle Kauffman, and Jonathan Liebowitz (Eds.) Land, Labor and Tenure: The Institutional Arrangements of Conflict and Cooperation in Comparative Perspective. Sevilla: Universidad de Sevilla.

Carmona, Juan, and Simpson, James (1999). "The 'Rabassa Morta' in Catalan Viticulture: The Rise and Decline of a Long Term Sharecropping Contract, 1670s-1920s." Journal of Economic History 59, 290-315.

Cleary, Mark C. (1989). Peasants, Politicians and Producers. The Organisation of Agriculture in France since 1918. Cambridge: Cambridge University Press.

Clique, Hubert (1931). Les caves coopératives de vinification en Bourgogne ainsi que dans les autres régions de la France et treize pays étranges. Paris: Recuiel Sirez.

Cosmo, Italo (1958). Le cantine sociali in Italia. Roma: Luigi Scialpi.

Cotta, Freppel (1935). Agricultural Co-operation in Fascist Italy. London: King \& Son. 
De Simone, Ennio (1979). La Toscana nell'età giolittiana. Agricoltura e agitazioni contadine. Napoli.

Dovring, Folke (1956). Land and Labor in Europe 1900-1950. The Hague: Martinus Nijhoff.

Elias de Molins, Jose (1904). Algunos datos y consideraciones sobre los trigos y vinos en España. Barcelona.

Ferrara, Antonio (1931). L'industria viti-vinicola dell'Algeria. Firenze: Istituto Agricolo Coloniale Italiano.

Frader, Laura (1991). Peasants and Protest, Agricultural Workers, Politics, and Unions in the Aude, 1850-1914. Berkeley: University of California Press.

Galassi, Francesco (1992). "Tuscans and Their Farms: The Economics of Share Tenancy in Fifteenth Century Florence." Rivista di storia economica 9, 77-94.

Galassi, Francesco, and Cohen, Jon (1994). "The Economics of Tenancy in Early Twentieth-century Southern Italy." Economic History Review 47, 585-600.

Galtier, Gaston (1958). Le Vignoble du Languedoc méditerranéen et du Roussillon. Paris: Université de Paris, 3 vols.

Garrido, Samuel (1996). Treballar en comú. El cooperativisme agrari a Espanya (1900-1936). Valencia: Edicions Alfons el Magnànim.

Gide, Charles (1926). Les associations coopératives agricoles. Paris: Association pour l'enseignement de la coopération.

Gide, Charles (1927). La coopération dans les pays latins: Amérique latine, Italie, Espagne, Roumanie, 1926-1927. Paris: Association pour l'enseignement de la coopération.

Gutiérrez Bringas, Miguel Angel (unpublished). "Land and Labour Productivity in Spanish Agriculture, 1765-1935: An Estimation by the Method of Prices."

Guyot, Jules (1861). Culture de la vigne et vinification. Paris: Georges Chamerot.

Henriksen, Ingrid (1999). "Avoiding Lock-in: Cooperative Creameries in Denmark, 1882-1903." European Review of Economic History 3, 57-78.

Hoffman, Philip (1984). "The Economic Theory of Sharecropping in Early Modern France." Journal of Economic History 42, 155-62.

Inchieste Parlamentare (1909). Relazione della Commissione d'Inchieste parlamentare sulle le condizioni dei lavoratori della terra nelle provincie meridionali e in Sicilia, Puglie, Roma, vol. 3.

Instituto de Reformas Sociales (1923). La rabassa morta y su reforma, Madrid: Minuesa de los Ríos.

Istituto Centrale di Statistica (ISTAT) (various years). Annuario statistico italiano, Roma.

ISTAT (1933). Annuario statistico italiano, Roma.

ISTAT (1940). Annuario statistico dell'agricoltura Italiana, anno 1939, Roma.

ISTAT (1954). Annuario di statistica agraria, Roma.

ISTAT (1958). Sommario di statistiche storiche italiane, Roma.

International Institute of Agriculture (1911 and 1915). Monographs on Agriculture. Co-operation in various countries. Rome: International Institute of Agriculture, 2 vols.

International Institute of Agriculture (1931). La coopération agricole. Rome: International Institute of Agriculture. 
Jaén, Celso (1904). Memoria sobre la tierra labrantia y el trabajo agrícola en la provincia de Navarra. Madrid: Ministerio de Agricultura, Industria y Comerico.

Lachiver, Marcel (1988). Vins, vignes et vignerons. Histoire du vignoble français. Paris: Fayard.

Lévy-Leboyer, Maurice (1971). "La décélération de l'économie française." Revue d'Histoire Economique et Sociale 49.

Lloyd, E.A. (1925). The Co-operative Movement in Italy. London.

Loubère, Leo A. (1978). The Red and the White: A History of Wine in France and Italy in the Nineteenth Century. Albany: State University of New York Press.

Loubère, Leo A. (1990). The Wine Revolution in France. The Twentieth Century. Princeton, NJ: Princeton University Press.

Majuelo, Emilio, and Pascual, Angel (1991). Del catolicismo agrario al cooperativismo empresarial. Setenta y cinco años de la Cooperativas navarras, 1910-1985. Madrid: Ministerio de Agricultura.

Maluquer de Motes, Jordi (1989). "Precios, salarios y beneficios." In Albert Carreras (Ed.) Estadísticas históricas de España siglos XIX-XX. Barcelona: Fundación Banco Exterior.

Marchesi, Francesco (1925). Le cantine sociali. Casale Monferrato: Marescalchi.

Marcilla Arrazola (1954). Tratado práctico de viticultura y enología españolas. Madrid: S.A.E.T.A., 2 vols.

Marescalchi, Arturo (1924). Como si abbassa il costo del vino. Casale Monferrato: Marescalchi.

Ministére du Travail (1934). Annuaire Statistique 1933. Paris: Impimerie nationale.

Ministerio de Agricultura (1933). Anuario estadístico de las producciones agrícolas, año 1932. Madrid: Imprenta Palomeque.

Ministero di agricoltura, industria e comercio (MAIC) (1892). Notizie e studi sulla agricoltura. Produzione e commercio del vino in Italia e all'Estero. Roma.

Ministero di agricoltura, industria e comercio (1908). "Cantine sociali ed associazioni di produttori di vini." Annali di agricoltura 1908, no. 255

Ministero di agricoltura, industria e comercio (1914). Il vino in Italia. Produzione-Commercio con l'Estero-Prezzi. Roma.

Mitchell, Brain R. (1975). European Historical Statistics, London: Macmillan.

Pan-Montojo, Juan (1994). La bodega del mundo. La vid y el vino en España (1800-1936). Madrid: Alianza.

Pan-Montojo, Juan, and Simpson, James (unpublished). El comercio internacional de vinos, 1850-1939.

Paul, Harry W. (1996). Science, Vine, and Wine in Modern France. Cambridge: Cambridge University Press.

Pazzagli, C. (1973). L'agricoltura toscana nella prima metà dell'800. Tecniche di produzione e rapporti mezzadrili. Firenze: Olshki Editore.

Pech, Rémy (1975). Entreprise viticole et capitalisme en Languedoc-Roussillon. Du phylloxéra aux crises de mévente. Toulouse: Presses de l'Université de Toulouse.

Piqueras, Juan (1981). La vid y el vino en el Pais Valenciano. Valencia: Instituto Alfons el Magnànim.

Po, Italo (1931). Le cantine sociali in Italia. Modena: Federazione Nazionale delle Cantine Sociali. 
Radi, Luciano (1962). I mezzadri. Le lotte contadine nell'Italia Centrale. Roma: Edizioni Cinque Luna.

Rivas Moreno, Francisco (no date). Los progresos del campo y la cooperación. Madrid: Hernando.

Roudié, Philippe (1994). Vignobles et vignerons du Bordelais (1850-1980. Bordeaux: Presses Universitaires de Bordeaux, 2nd. ed.

Sabio, Alberto (1995). Viñedo y vino en el Campo de Cariñena. Zaragoza: Institución Fernando el Católico.

Scholliers, Peter, and Zamagni, Vera (1995). Labour's Reward. Real Wages and Economic Change in $19^{\text {th }}$ and $20^{\text {th }}$ Century Europe. Aldershot: Edward Elgar.

Simpson, James (1985). "Agricultural Growth and Technological Change: The Olive and Wine in Spain, 1860-1936." Ph.D. dissertation, University of London.

Simpson, James (1995). Spanish Agriculture. The Long Siesta, 1765-1965. Cambridge: Cambridge University Press.

Smith, Harvey (1975). "Work Routine and Social Structure in a French Village: Cruzy, Hérault, in the Nineteenth Century." Journal of Interdisciplinary History 5, 357-382.

Smith, Harvey (1978). "Agricultural Workers and the French Wine Growers Revolt of 1907." Past and Present 79, 101-125.

Van Zanden, Jan L. (1991). "The First Green Revolution: The Growth of Production and Productivity in European Agriculture, 1870-1914." Economic History Review 44, 215-39.

Warner, Charles K. (1960). The Winegrowers of France and the Government since 1875. New York: Columbia University Press. 